\title{
PEMBERDAYAAN MASYARAKAT PASCA PENUTUPAN LOKALISASI “MOROSENENG” DI KECAMATAN BENOWO KOTA SURABAYA
}

\author{
Agung Bayu Murti ${ }^{1}$, Andi Iswoyo ${ }^{2}$, M. Syaiful Arif ${ }^{3}$, Dian Purnama Sari ${ }^{4}$, Dewi Rosaria Indah ${ }^{5}$ \\ ${ }^{1}$ Universitas Wijaya Putra \\ ${ }^{2}$ Universitas Wijaya Putra \\ ${ }^{3}$ Universitas Wijaya Putra \\ ${ }^{4}$ STKIP Bina Insan Mandiri \\ ${ }^{5}$ STKIP Bina Insan Mandiri \\ agungbayu@uwp.ac.id, andi@uwp.ac.id, msyaiful.arif@uwp.ac.id, \\ dianpurnama@stkipbim.ac.id, dewirosaria@stkipbim@ac.id
}

\begin{abstract}
Abstrak
Wilayah yang menjadi sasaran Program Kemitraan Wilayah ini adalah Kelurahan Kandangan dan Kelurahan Sememi Kecamatan Benowo Kota Surabaya. Kedua Kelurahan tersebut merupakan wilayah eks Lokalisasi "Moroseneng" yang ditutup Pemerintah Kota Surabaya pada akhir tahun 2013. Permasalahan yang dihadapi Motivasi bekerja dan berwirausaha pasca penutupan lokalisasi masih rendah. Munculnya banyak pengangguran/PMKS, Pemberdayaan masyarakat belum tergarap dengan maksimal, belum pada upaya membuat masyarakat berwirausaha secara mandiri. Kurangnya kesadaran masyarakat dalam membantu tumbuh kembang anak dan pendidikan.

Metode yang dipakai dalam pelaksanaan program antara lain; Koordinasi secara terus menerus dengan perangkat terkait, Studi Kelayakan Usaha, Pelatihan Usaha, Pendampingan Usaha, Perbantuan dalam hal kemudahan akses pemasaran dan jaringan, promosi usaha, akses pembinaan dari Dinas Koperasi dan UMKM dan Disperindag, Penyelenggaraan event pameran,.

Hasil yang telah dicapai adalah Terlaksananya Kegiatan Fasilitasi Inkubasi Usaha Mandiri, berupa kegiatan Motivasi Wirausaha, Kegiatan Pelatihan Produksi (peyek semanggi dan bronies kering), dan melakukan pendampingan wirausaha untuk usaha yang berpotensi dikembangkan (batik, sambel dan layanglayang) dengan pemberian ketrampilan Manajemen Usaha, Tercapainya menjadi peserta Pameran di Kelurahan kandangan dan Mlaku-mlaku nang Tunjungan,Terlaksanannya Pembinaan Wilayah dengan Konsep Kampung Pendidikan Kampunge Arek Surabaya(KPKAS), Terliputnya Kegiatan PKW ini di SBO TV, dan media cetak Jawa Pos.
\end{abstract}

Kata Kunci : Kata Kunci : Pemberdayaan Masyarakat, SDM, Ekonomi, Pendidikan, Sosial 


\section{PENDAHULUAN}

Prostitusi menjadi masalah yang mendasar bagi sebuah Kota Surabaya yang dalam desainnya akan menjadi Kota yang Layak Anak. Untuk mengatasi masalah, Pemerintah Kota Surabaya telah menutup semua lokalisasi yang ada di Kota Surabaya, yaitu lokalisasi Kermil Tambak asri, Dupak Bangunsari, lokalisasi Moroseneng dan lokalisasi Dolly Jarak. Menurut Tri Rismaharini, tujuan utama penutupan lokalisasi adalah untuk menyelamatkan generasi bangsa. Tidak dipungkiri sebagai kebijakan yang menyangkut hajat hidup orang banyak, penutupan lokalisasi Dolly dan lokalisasi lainnya di Surabaya menjadi pro dan kontra. Bagi pihak yang pro-pemerintah penutupan lokalisasi tersebut merupakan tindakan sewajarnya sebagai akibat dari dampak negatif-sistemik terhadap masyarakat bahkan generasi muda harapan bangsa. Sebaliknya, bagi pihak yang kontra, kebijakan tersebut dianggap sebagai diskriminasi terhadap hak-hak individu dan lebih jauh lagi sebagai bentuk pelanggaran hak asasi manusia (Zaenuri, 2014).

Selama adanya lokalisasi, banyak masyarakat sekitar yang menggantungkan kehidupannya pada lokalisasi, diantara mereka ada yang menjadi pengelola lokalisasi (mucikari), tukang parkir, penjual makanan dan minuman, laundry, dan lain-lain. Keberadaan lokalisasi sangat membantu perekonomian masyarakat yang menggantungkan hidupnya di lokalisasi tersebut, yang mulanya tingkat perekonomian masyarakat rendah menjadi semakin meningkat dan hidupnya semakin sejahtera. Sehingga tidak heran, ketika lokalisasi ditutup banyak masyarakat disekitar lokalisasi diantaranya para PSK dan para warga yang menggantungkan hidupnya di lokalisasi menolak akan kebijakan Pemerintah Kota Surabaya. Jika para PSK dan mucikari mendapatkan pesangon dan atau ganti rugi dari Pemerintah Kota Surabaya, beda halnya dengan masyarakat terdampak, akibat yang ditimbulkan dari penutupan lokalisasi itu tidak hanya pada perekonomian akan tetapi juga berakibat pada kehidupan sosial masyarakat.

Kehidupan ekonomi masyarakat yang menggantungkan kehidupannya di lokalisasi pasca penutupan diantaranya masyarakat kehilangan pekerjaan sehari-hari yang selama ini mereka lakukan selama lokalisasi masih buka, mulai dari pedagang makanan yang kelililing, pedagang makanan dan minuman yang menetap, tukang parkir, bisnis laundry pakaian, toko-toko kelontong, dan yang paling merasakan dampaknya adalah pengelola lokalisasi. Kini pendapatan pengelola lokalisasi dan masyarakat sekitar mengalami penurunan yang drastis dari penghasilan yang biasanya. Hampir $3 / 4$ persen penghasilan mereka hilang. Dampak penutupan lokalisasi terhadap kehidupan sosial ekonomi masyarakat sekitar lokalisasi, membuat masyarakat mengalami perubahan dalam kehidupan sosial ekonominya, untuk itu masyarakat perlu beradaptasi dengan kondisi kehidupan sosial ekonomi yang mengalami perubahan sesudah terjadinya penutupan lokalisasi.

Adapun permasalahan yang relevan dengan permasalahan prioritas yang akan ditangani bersama dalam Program Kemitraan Wilayah antara Perguruan Tinggi Pengusul dalam hal ini Universitas Wijaya Putra, Pemerintah Kota Surabaya dan Perguruan Tinggi Mitra yaitu STKIP Bina Insan Mandiri, disajikan dalam tabel berikut:

Tabel Permasalahan dan Solusi

\begin{tabular}{|c|c|c|}
\hline No. & Persoalan & Solusi \\
\hline \multicolumn{3}{|c|}{ BIDANG UTAMA : SUMBER DAYA MANUSIA } \\
\hline 1 & $\begin{array}{l}\text { Akses tenaga kerja untuk mendapatkan pekerjaan } \\
\text { dengan hanya berbekal ijasah SMA/Sederajat lebih } \\
\text { sulit di Kota Surabaya }\end{array}$ & Penyuluhan dan Pelatihan Kompetensi Kerja \\
\hline 2 & $\begin{array}{l}\text { Motivasi berwirausaha pasca penutupan lokalisasi } \\
\text { masih rendah, karena terbiasa mengandalkan } \\
\text { pendapatan dari adanya lokalisasi. }\end{array}$ & $\begin{array}{l}\text { Workshop Open Mind secara berkelanjutan } \\
\text { untuk menumbuhkan jiwa wirausaha }\end{array}$ \\
\hline \multicolumn{3}{|c|}{ BIDANG UTAMA : EKONOMI MASYARAKAT } \\
\hline 3 & $\begin{array}{l}\text { Munculnya banyak pengangguran/PMKS, dimana } \\
\text { masyarakat yang dulunya menggantungkan hidupnya } \\
\text { dari lokalisasi seperti juru parkir, penjual rokok, } \\
\text { loundry, pemilik kos-kosan, dll tidak dapat bekerja } \\
\text { pasca penutupan lokalisasi }\end{array}$ & $\begin{array}{l}\text { Open Mind wirausaha, berupa penyuluhan dan } \\
\text { workshop untuk membukan pikiran masyarakat } \\
\text { untuk mau berwirausaha }\end{array}$ \\
\hline 4 & Partisipasi masyarakat eks lokalisasi Moroseneng & Usaha, ditujukan \\
\hline
\end{tabular}




\begin{tabular}{|c|c|c|}
\hline & $\begin{array}{l}\text { pada program-program dari Pemkot Surabaya lebih } \\
\text { rendah dibandingkan dengan di eks lokalisasi Dolly, } \\
\text { sehingga diperlukan upaya untuk segera menjadikan } \\
\text { eks lokalisasi Moroseneng seperti Dolly sekarang }\end{array}$ & $\begin{array}{l}\text { mengetahui lebih jauh tentang bakat dan minat } \\
\text { usaha apa yang dimiliki oleh warga, sehingga } \\
\text { Program akan lebih tepat sasaran dan } \\
\text { berkelanjutan. }\end{array}$ \\
\hline \multirow[t]{9}{*}{5} & \multirow{3}{*}{$\begin{array}{l}\text { a. Peningkatan pendapatan masyarakat terdampak } \\
\text { penutupan lokalisasi belum tergarap dengan } \\
\text { maksimal }\end{array}$} & Pelatihan Perencanaan dan Produksi/ Jasa \\
\hline & & Pelatihan Pengenalan Bahan Baku dan Pemasok \\
\hline & & Pelatihan Alat dan Metode Produksi/Layanan \\
\hline & \multirow{6}{*}{$\begin{array}{l}\text { b. Pelatihan-pelatihan untuk meningkatkan motivasi } \\
\text { masyarakat dalam berwirausaha masih } \\
\text { berdasarkan permintaan dari warga dan tanpa } \\
\text { melihat bakat/minat warga, belum berkelanjutan } \\
\text { dan masih bersifat sporadis/insidental } \\
\text { c. Pelatihan berwirausaha hanya terbatas pada } \\
\text { pelatihannya dan pemberian bahan pelatihan, } \\
\text { belum pada upaya membuat masyarakat } \\
\text { berwirausaha secara mandiri. }\end{array}$} & Pelatihan Quality Control \\
\hline & & $\begin{array}{l}\text { Pelatihan Keuangan; Modal, Biaya, HPP, } \\
\text { Laporan Keuangan }\end{array}$ \\
\hline & & $\begin{array}{l}\text { Pemasaran; Riset Pasar, Marketing Mix, } \\
\text { Segmenting, Targeting and Positioning }\end{array}$ \\
\hline & & $\begin{array}{l}\text { Start Up Business with BMC (Business Model } \\
\text { Canvas) }\end{array}$ \\
\hline & & $\begin{array}{l}\text { Legalitas Usaha; membantu pengurusan } \\
\text { perijinan; workshop aspek lingkungan usaha. } \\
\text { Setelah mendapatkan perijinan, pembinaannya } \\
\text { didampingi bersama dengan Dinas Koperasi dan } \\
\text { UMKM Kota Surabaya dan atau Dinas } \\
\text { Perindustrian dan Perdagangan }\end{array}$ \\
\hline & & $\begin{array}{l}\text { Teknologi Tepat Guna; pemilihan teknologi } \\
\text { yang tepat dalam proses produksi. }\end{array}$ \\
\hline 6 & $\begin{array}{l}\text { Belum adanya pendampingan dan perbantuan dalam } \\
\text { akses terhadap permodalan, teknologi dan pemasaran }\end{array}$ & $\begin{array}{l}\text { Pendampingan Usaha; guna mendapatkan akses } \\
\text { permodalan, teknologi dan pemasaran }\end{array}$ \\
\hline \multirow[t]{2}{*}{7} & \multirow[t]{2}{*}{$\begin{array}{l}\text { Belum termanfaatkannya sarana yang telah } \\
\text { disediakan oleh Pemkot untuk warga berwirausaha } \\
\text { seperti Sentra PKL, Lapangan Sepak Bola, Lapangan } \\
\text { Futsal, Taman Bermain, Rumah Kreatif, dll. secara } \\
\text { optimal. }\end{array}$} & $\begin{array}{l}\text { Memanfaatkan sarana untuk mengenalkan usaha } \\
\text { dengan mengadakan kegiatan-kegiatan rutin } \\
\text { seperti Kejuaraan olah raga; bazar dan pameran } \\
\text { UMKM; Festival Seni \& Budaya. Kegiatan ini } \\
\text { akan difasilitasi oleh Dinas P5A Kota Surabaya }\end{array}$ \\
\hline & & $\begin{array}{l}\text { Branding Wilayah; menjadikan wilayah sasaran } \\
\text { memiliki ikon yang mudah dikenal }\end{array}$ \\
\hline 8 & $\begin{array}{l}\text { Belum adanya Kelompok Usaha Ekonomi } \\
\text { Masyarakat yang menampung bakat/minat warga } \\
\text { dalam berwirausaha bersama }\end{array}$ & $\begin{array}{l}\text { Membentuk Kelompok Usaha Ekonomi } \\
\text { Masyarakat (KUEM) terutama bagi masyarakat } \\
\text { sasaran yang belum bisa berwirausaha secara } \\
\text { mandiri }\end{array}$ \\
\hline \multirow[t]{2}{*}{9} & \multirow[t]{2}{*}{$\begin{array}{l}\text { Belum adanya kader/fasilitator pemberdayaan } \\
\text { masyarakat yang mampu mendampingi masyarakat } \\
\text { dalam berwirausaha }\end{array}$} & $\begin{array}{l}\text { Membentuk Kader Pemberdayaan Masyarakat } \\
\text { untuk memudahkan masyarakat dalam } \\
\text { memperoleh akses pendampingan; }\end{array}$ \\
\hline & & $\begin{array}{l}\text { Pendampingan melalui Pusat } r \text { Studi } \\
\text { Kewirausahaan di Kampus PT } \\
\text { (Universitas Wijaya Putra) yang dijadikan } \\
\text { tempat bagi UMKM mitra untuk berkonsultasi } \\
\text { tentang berwirausaha. }\end{array}$ \\
\hline \multicolumn{3}{|c|}{ BIDANG UTAMA : PENDIDIKAN, SOSIAL DAN LINGKUNGAN } \\
\hline \multirow[t]{2}{*}{10} & \multirow{2}{*}{$\begin{array}{l}\text { Kurangnya kesadaran masyarakat dalam membantu } \\
\text { belajar anak dengan menyediakan waktu bagi anak } \\
\text { belajar dalam keluarga }\end{array}$} & $\begin{array}{l}\text { Memberikan pelatihan tentang Psikologi anak } \\
\text { dan Pembelajaran Keluarga }\end{array}$ \\
\hline & & $\begin{array}{l}\text { Memfasilitasi masyarakat untuk meningkatkan } \\
\text { kesadaran warga melalui Pusat Pembelajaran } \\
\text { Keluarga yang ada di Kampus Universitas } \\
\text { Wijaya Putra }\end{array}$ \\
\hline 11 & $\begin{array}{l}\text { Belum adanya taman bacaan, wahana bermain dan } \\
\text { berekpresi yang membantu anak dalam mencegah } \\
\text { dampak negatif lingkungan pasca penutupan }\end{array}$ & Mengembangkan Taman Bacaan Masyarakat \\
\hline
\end{tabular}




\begin{tabular}{|c|c|c|}
\hline & lokalisasi & \\
\hline 12 & $\begin{array}{l}\text { Belum tersedianya forum bagi anak sebagai wadah } \\
\text { mereka bertukar fikiran, diskusi, curhat dan } \\
\text { menyelesaikan masalah yang mereka hadapi dengan } \\
\text { bimbingan rekan sebaya. }\end{array}$ & $\begin{array}{l}\text { Membentuk Forum Anak sebagai wadah mereka } \\
\text { bertukar fikiran, diskusi, curhat dan } \\
\text { menyelesaikan masalah yang mereka hadapi } \\
\text { dengan bimbingan rekan sebaya. }\end{array}$ \\
\hline 13 & $\begin{array}{l}\text { Keluarga belum menjalankan fungsi pengasuhan dan } \\
\text { pendidikan informal atau penanaman nilai-nilai }\end{array}$ & $\begin{array}{l}\text { Menciptakan Kampung Belajar; kampung yang } \\
\text { memiliki kepedulian dan komitmen untuk } \\
\text { menjamin terlaksananya lingkungan yang } \\
\text { mendukung pendidikan / belajar anak }\end{array}$ \\
\hline 14 & $\begin{array}{l}\text { Lokalisasi telah membawa dampak negatif yang } \\
\text { sangat besar pada masyarakat Kec. Benowo, pasca } \\
\text { penutupan lokalisasi, kehidupan masyarakat } \\
\text { berangsur normal \& positif namun citra masyarakat } \\
\text { tetap melekat sebagai kampung lokalisasi }\end{array}$ & $\begin{array}{l}\text { Menciptakan Kampung Asuh; kampung yang } \\
\text { memiliki kesadaran terhadap pengasuhan anak } \\
\text { sesuai dengan kebutuhan tumbuh kembang anak }\end{array}$ \\
\hline 15 & $\begin{array}{l}\text { Lingkungan yang kurang sehat, dikarenakan tingkat } \\
\text { kesadaran warga tentang kesehatan masih kurang, } \\
\text { misalnya merokok disembarang tempat \& dekat } \\
\text { anak-anak, buang air besar sembarangan, minuman } \\
\text { keras, lingkungan yang kurang hijau/asri, }\end{array}$ & $\begin{array}{l}\text { Menciptakan Kampung Sehat; kampung yang } \\
\text { memberikan suatu kondisi fisik, mental dan } \\
\text { sosial yang merupakan satu kesatuan dan bukan } \\
\text { hanya bebas dar penyakit atau kecacatan tetapi } \\
\text { kehidupan yang nyaman dan harmonis }\end{array}$ \\
\hline 16 & $\begin{array}{l}\text { Wilayah merupakan eks lokalisasi Moreseneng dan } \\
\text { masih terdapat beberapa tempat hiburan malam yang } \\
\text { buka sehingga kurang baik bagi perkembangan } \\
\text { psikologis anak dan tingkat keamanan lingkungan } \\
\text { masih cenderung rawan }\end{array}$ & $\begin{array}{l}\text { Menciptakan Kampung Aman; kampung yang } \\
\text { menjamin keamanan dan keselamatan } \\
\text { anak/warga dari segala bentuk, jenis kekerasan, } \\
\text { penelantaran, eksploitasi serta resiko kecelakaan } \\
\text { dan kebencanaan }\end{array}$ \\
\hline 17 & $\begin{array}{l}\text { Belum tersedianya tempat / kesempatan / fasilitas } \\
\text { bagi anak-anak untuk melakukan ekspresi, kreasi dan } \\
\text { inovasi sesuai dengan minat dan bakat anak }\end{array}$ & $\begin{array}{l}\text { Menciptakan Kampung Kreatif dan Inovatif; } \\
\text { kampung yang menyediakan ruang, waktu, } \\
\text { tempat untuk berekspresi \& inovasi bagi anak }\end{array}$ \\
\hline
\end{tabular}

\section{METODE PELAKSANAAN}

Pendekatan yang digunakan dalam pelaksanaan Program Kemitraan Wilayah ini, antara lain : 1 . Koordinasi secara terus menerus dengan perangkat RW, Kelurahan, Kecamatan dan Dinas terkait, 2. Studi Kelayakan Usaha, untuk mengetahui bakat dan minat wirausaha warga, 3. Penyuluhan dan Workshop, pada kegiatan open mind, Start Up Business with BMC, Penyiapan Kader Pemberdayaan Masyarakat, Pembentukan KUEM, Legalitas Usaha, dan KP-KAS., 4. elatihan Usaha sesuai bakat minat warga di bidang kuliner, fashion, wisata, EO. Pelatihan ini meliputi Perencanaan dan Produksi/Jasa, Pengenalan Bahan Baku dan Pemasok, Alat dan Metode Produksi/Layanan, Quality Control, Keuangan dan Pemasaran, 5. Pendampingan Usaha melalui kegiatan memotivasi jiwa wirausaha, pendampingan pengurusan ijin usaha dan pendampingan pasca pelatihan, 6. Perbantuan dalam hal koordinasi dengan dinas terkait dalam hal kemudahan akses memperoleh permodalan, teknologi, pemasaran dan jaringan, promosi usaha, akses pembinaan dari Dinas Koperasi dan UMKM dan Disperindag, kemudahan dalam mengikuti pameran, bazar, festival, dll, 7. Penyelenggaraan event olahraga, pameran, bazar, festival, 8 . Branding Kawasan agar lebih dikenal publik di Surabaya dan luar Surabaya

Dalam pelaksanaan kegiatan Program Kemitraan Wilayah ini, Pemerintah Kota Surabaya dalam hal ini melalui Dinas Pengendalian Penduduk, Pemberdayaan Perempuan dan Perlindungan Anak (DP5A) telah bersepakat dengan Universitas Wijaya Putra dan STKIP Bina Insan Mandiri selaku Perguruan Tinggi Mitra. Adapun kontribusi Pemerintah Kota Surabaya dalam PKW ini, antara lain: 1. Pemerintah Kota Surabaya menyediakan dana pendamping untuk mendukung program-program yang dicanangkan dalam Program Kemitraan Wilayah ini dalam bentuk inkind, 2. Memfasilitasi pelaksanaan program yang sudah direncanakan melalui; penyediaan sarana pelatihan, instruktur, fasilitator, akomodasi, penggunaan Rumah Kreatif, 3. Membantu memfasilitasi komunikasi dengan Dinas/SKPD lainnya di lingkungan Pemerintah Kota Surabaya dalam hal; pengurusan ijin usaha, instruktur, pendampingan, akses permodalan, pameran yang diselenggarakan Pemkot Surabaya, 4. Membantu promosi dan memperluas akses jaringan UMKM, 5. Menyertakan staf dari Dinas P5A dalam kegiatan PKW yang terkait dengan bidang tugas sehari-harinya, 6 . Membantu memobilisasi masyarakat untuk berpartisipasi dalam PKW ini. 


\section{HASIL DAN PEMBAHASAN}

Program dan Kegiatan untuk mengatasi Permasalahan Ekonomi dan Sumber Daya Manusia adalah dengan Program Fasilitasi Inkubasi Usaha Mandiri. Program ini terdiri dari beberapa kegiatan pelatihan dan pendampingan, adapun beberapa pelatihan yang diberikan kepada peserta terdapat tujuh jenis pelatihan yaitu : 1. Pelatihan Motivasi Wirausaha, 2. Pelatihan Keterampilan Wirausaha, 3. Pelatihan Manajemen Pemasaran, 4. Pelatihan Manajemen Keuangan, 5. Pelatihan Manajemen Organisasi dan SDM, 6. Penyuluhan Legalitas Usaha dan Lingkungan, 7. Penyuluhan Akses Permodalan

Setelah rangkaian pelatihan selesai kemudian dilanjutkan dengan pendampingan. Pendampingan ini memfasilitasi peserta agar dapat konsultasi terkait hasil mereka mempraktekkan ilmu yang sudah diberikan pada beberapa pelatihan sebelumnya. Disamping menerima konsultasi para narasumber pendampingan juga memberikan tips dan trik untuk mengatasi permasalahan-permasalahan yang dihadapi peserta. Adapun jenis pendampingan yaitu : 1. Pendampingan Manajemen Produksi, 2. Pendampingan Manajemen Pemasaran, 3. Pendampingan Manajemen Keuangan, 4. Pendampingan SDM, 5. Pendampingan Legalitas Usaha, 6. Pendampingan Lingkungan, 7. Pendampingan Akses Permodalan. Hasil yang dicapai adalah Terlaksananya Kegiatan Fasilitasi Inkubasi Usaha Mandiri, mulai dari kegiatan Motivasi Wirausaha, Kegiatan Pelatihan Produksi(peyek semanggi dan bronies kering), serta dilakukan pendampingan wirausaha untuk kegiatan usaha yang berpotensi untuk dikembangkan (batik, sambel dan layang-layang) sampai dengan pemberian ketrampilan Manajemen Usaha.

Program dan kegiatan yang dilakukan untuk mengatasi Permasalahan Pendidikan, Sosial dan Lingkunganadalah dengan Konsep Kegiatan Pembinaan Wilayah, gegiatan ini adalah dengan mengacu pada Konsep KPKAS (Kampung Pendidikan Kampunge Arek Suroboyo) yang telah dicanangkan Pemerintah Kota Surabaya sejak tahun 2014, KPKAS ini ditujukan untuk menciptakan kondisi daerah tinggal (kampung) yang nyaman dan aman bagi proses tumbuh kembang anak dalam dukungan masyarakat yang menjamin pemenuhan hak anak dan mengupayakan perlindungan anak secara optimal. Konsep ini terdiri dari beberapa kampung yaitu :1. Kampung Belajar, 2. Kampung Sehat, 3. Kampung Asuh, 4. Kampung Kreatif, 5. Kampung Aman. Kegiatan Fasilitasi Pembinaan Wilayah ini juga dibantu oleh Kegiatan Kuliah Kerja Nyata (KKN) mahasiswa Universitas Wijaya Putra, sehingga semakin mempermudah implementasi Konsep KPAS

Kegiatan peliputan media juga dilakukan untuk menambah promosi akan adanya kegiatan pemberdayaan masyarakat di bekas eks lokalisasi, diharapkan dengan diliput oleh media elektronik dan media cetak kegiatan ini akan lebih intens mendapat perhatian dari pemerintah kota dan pihak swasta untuk ikut berpartisipasi dalam pemberdayaan masyarakat. Kegiatan ini telah diliput oleh SBO TV dan ditayangkan tanggal 3 September 2018 dan Jawa Pos 16 September 2018

\section{KESIMPULAN}

Program Pemberdayaan Masyarakat pasca penutupan Eks Lokalisasi Moroseneng dinilai cukup berhasil dalam memberdayakan masyarakat yakni menghasilkan embrio-embrio bisnis di daerah eks lokalisasi , adanya peningkatan partisipasi masyarakat dalam ikut serta dalam program pemberdayaan, adanya sinergi kerjsasama antara pemerintah, akademis dan masyarakat. dan terliputnya oleh media elektronik dan media cetak Tentunya upaya ini perlu dilanjutkan secara intens dengan program yang berkelanjutan, tetap mempertahankan sinergi yang telah terjalin dengan baik antara pihak pemerintah, akademis dan masyarakat serta mengundang pihak swasta(perusahaan) untuk ikut serta dalam pemberdayaan melalui program Corporate Social responsibilities (CSR). Dengan demikian dalam jangka panjang akan dapat mengubah stigma jelek kawasan eks lokalisasi menjadi Kampung Kreatif sesuai yang dicita-citakan oleh Pemerintah Kota Surabaya.

\section{REFERENSI}

BPS Surabaya, 2016, Kecamatan Benowo dalam Angka 2016, Surabaya

Peraturan Daerah Pemerintah Kota Surabaya Nomor 10 Tahun 2016 Tentang Rencana Pembangunan Jangka Menengah Daerah Kota Surabaya Tahun 2016 - 2021. Sekretariat Kota Surabaya
Zaenuri Achmad
2014
Lokalisasi
dan Hak
Asasi
Manusia,
Kompasina, http://www.kompasiana.com/ahmad zaenuri/lokalisasi-dan-hak-asasimanusia_54f6edfea33311c45c8b4b82, diakses tanggal 2 Mei 2017 